\title{
The Box, the Fish, and Lost Homes
}

\author{
Suranjana Choudhury
}

ABSTRACT: The Partition of 1947 is a seminal episode in the history of the Indian subcontinent. Partition is still a living reality; it continues to define the everydayness of lives in the partitioned states. Memory is an important topic in the field of Partition Studies: the act of remembering and the subject of remembrance illuminate our understanding of Partition in more ways than one. Personal memories hold special significance in this regard. This article comprises two personal memory pieces on the cascading effects of Partition in individuals' lives. The first story is a retelling of my grandmother's experience of displacement and her subsequent relocation in newly formed India. The story brings forth memories associated with her wedding jewelry box, which she brought with her across the border. The second story focuses on the life experiences of my domestic helper, a second generation recipient of Partition memories.

KEYWORDS: displacement, home, India, memories, Partition

\section{Introduction}

The Partition of 1947 is one of the most defining moments of the history of the Indian subcontinent. Maps were redrawn along religious lines to displace millions on both sides of the border. People lost their homes, their loved ones overnight. Partition continues to exist as a living reality; none can deny its everydayness. Like many other chapters of history across the world, Partition too has generated multiple narratives. It is possible to come across a rich repository of personal memories, community chronicles beyond official archives and documentations. These voices illuminate diverse meanings of partitioned existence. The past resurfaces through these narratives intimately, intriguingly. The following tiny life stories contribute to the vastness and multiplicity of Partition memories. Story I focuses on my grandmother, who experienced Partition. The focal point is her jewelry box, which she brought along with her. This seemingly insignificant item reinforces the idea of partitioned lives. Granny's aged jewelry box has many stories to tell. The second narrative is about Rinadi, the domestic helper who comes every day to help me with cooking. She is a second-generation recipient of Partition memories. Her parents crossed borders to find a new home in one of the villages of Assam. She migrated again from her village to the city of Shillong in search of a better life. The comforts and warmth of home are replaced with the difficulties and challenges of a city life. Rinadi's story is a layered tale of a perennial sense of homelessness. 


\section{Story I}

I assumed during my childhood that boxes bore marks of Partition and homelessness. Some boxes are special. This box had lost its home in Sunamganj, which was part of Sylhet Division in undivided India. Sylhet remained with East Pakistan during Partition. This box was forced to migrate; it was not given any choice. Humans had no choice during that time. The displacement of 1947 damaged lives, destroyed souls. The box migrated with my granny to Silchar in Assam; it crossed borders, suppressing heavy sighs. When Partition happened in 1947, my grandparents had to leave their home behind and migrate to this side of newly reconfigured India. My grandparents, like most other displaced people of their generation, could not anticipate the ugliness of this bloody episode. History decided otherwise. The box is ancient now; it looks rusty. Once it was filled with gold jewelry that my granny was given as her wedding gift. I have received this box as an heirloom. Like many unnamed women of her generation, she too sold off her wedding jewelry to build a house for our displaced family in Silchar. She told us stories about her lost home, her people. Her memories conveyed unmistakably the pain of displacement and emotional distress for having lost her home. The realms of my everyday have been molded by this repository of innumerable anecdotes. I lost her at a very early phase of my life. She continues to define roots for me in my life, this box too along with her.

Figure 1. Grandma's jewelry box - the preserver of memories and more. My grandmother received her jewelry box as her wedding gift. Most of the ornaments, after Partition, had been used to build a new house out of almost nothing. The box remains, and it stores layers of memories and family tales. Grandma and her generation of displaced people continue to live through such boxes.

Photograph by the author.

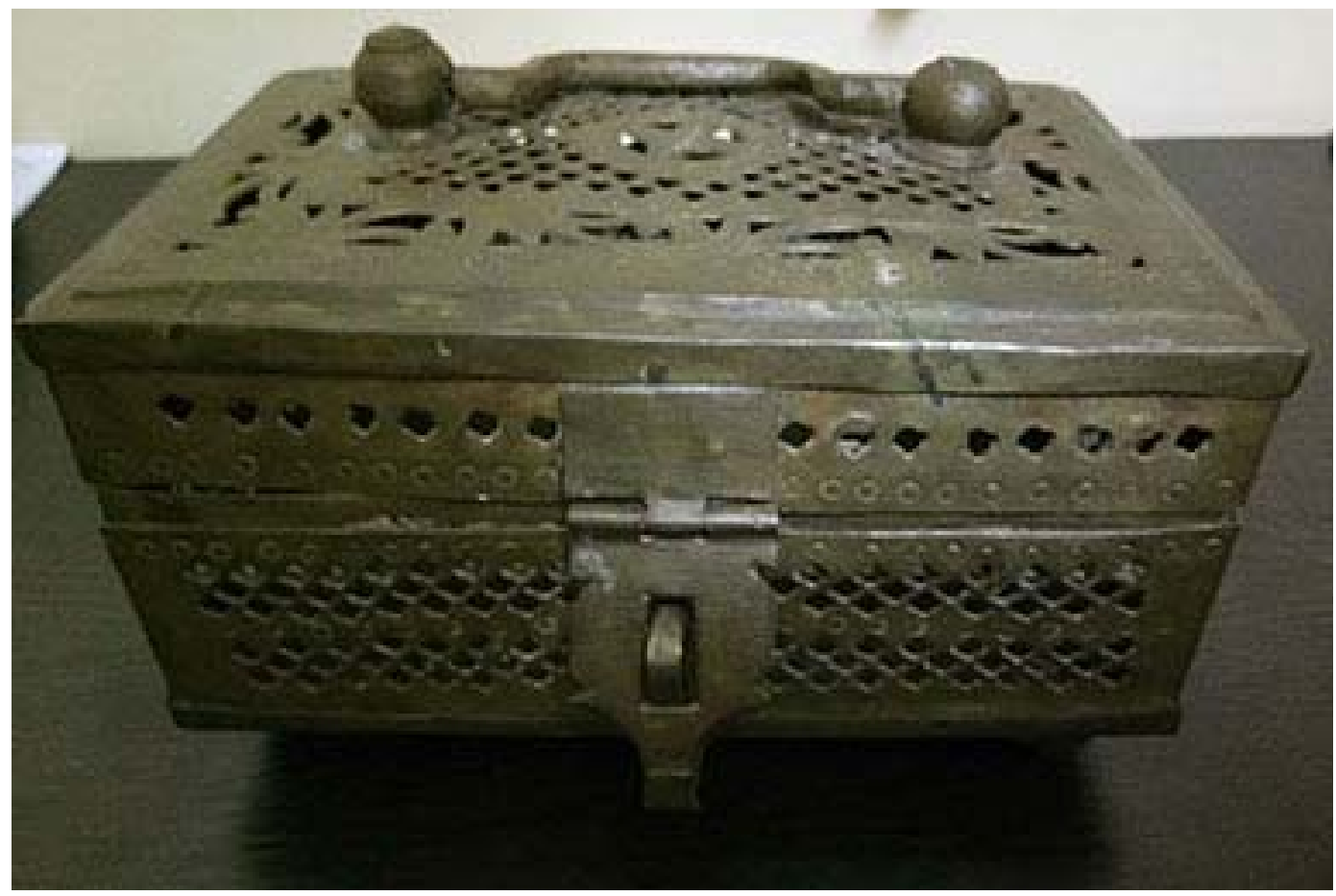




\section{Story II}

Some evenings, while processing the freshly purchased small fishes (mourala, the celebrated moka mach of Sylhetis, or poonti), Rinadi tells me stories about her village. The sight of puny, silvery fishes induces her to chronicle the taste of her village. Her village now resides in her memories. Through such stories she weighs her past against her future, story-laden past against a tentative future. She hardly visits her village these days, yet it delivers her a sense of pride, a possession amidst her innumerable dispossessions. She looks for this primal space of her memories in the segregated heads of fishes, in moist green vegetables she is yet to chop. Like the villages of most stories, her village too is lush and beautiful. Her stories transform this particular village of Nalbari into an archetypal one, an idyllic village that embraces many forms of prosperity and richness. She left her village long ago and migrated to Shillong to acquire a modern and urban life. I know this displacement has not really offered her a better life. She has to toil day and night for a living. In the course, she has lost her lustrous fishes, raw mangoes, swelling ponds. All displacements entail a sense of loss, a measure of pain. She consoles herself through her constant endeavors to discover her lost village in many forms and shapes of the present, the here and now. Her nostalgia is not an admission of defeat; it is an affirmation that none can resist change. She negotiates her experiences of home and homelessness through such personal discoveries.

SURANJANA CHOUDHURY teaches literature at North Eastern Hill University, Shillong. Her essays and reviews have been published in different journals and magazines including Scroll.in, The Wire, Biblio, The Statesman, Café Dissensus, Humanities Underground, Coldnoon Travel Poetics and Elsewhere. She may be contacted at suranjanaz@gmail.com. 